\title{
PERSEPSI MAHASISWA TERHADAP PRAKTIKUM DARING MATA KULIAH KIMIA ANALISIS
}

\author{
Akhmad Al-Bari, Romadhiyana Kisno Saputri \\ Universitas Nahdlatul Ulama Sunan Giri \\ albari@unugiri.ac.id
}

\begin{abstract}
During the COVID-19 pandemic period, every education unit requires an online learning process, not only for theoretical courses, but also for practical courses, including analytical chemistry practicum courses. Student perceptions of online lectures can help students in implementing the process lectures during the Covid 19 pandemic, because a good and correct lecture will belp students improve their understanding and knowledge of students. This study aims to find out students perception about online practicum in analytical chemistry. This research is a qualitative descriptive study. The sample was taken using simple random sampling consisted of 45 students. Data were obtained using questionnaires and in-depth interviews. Student perceptions were seen from three aspects, teaching and learning process, the ability of lecturers, facilities and infrastructure which were assessed using a likert scale. The data analysis by qualitative analysis, consisting of data collection, data reduction, data presentation, and conclusion drawing. Student perceptions in all aspects have a mean of 64.95\% so that students 'perceptions of online practicum in analytical chemistry are positive. Students' perceptions of teaching and learning aspects have a value of $69.57 \%$ which indicates a positive perception, on aspects of lecturer competence have a value. $77.90 \%$ which shows a positive perception of the infrastructure aspect has a value of $47.39 \%$ which indicates a positive perception.

Keywords: students perceptions; online practicum; Analytic Chemistry
\end{abstract}

\begin{abstract}
ABSTRAK
Selama masa pandemi COVID-19 mengharuskan setiap satuan pendidikan melaksanakan proses pembelajaran daring tidak hanya untuk mata kuliah teori, namun juga untuk mata kuliah praktik, termasuk mata kuliah praktikum kimia analisis. Persepsi mahasiswa terhadap kuliah online dapat membantu mahasiswa dalam pelaksanaan proses perkuliahan di masa pandemi covid 19, karena perkuliahan yang baik dan benar akan membantu mahasiswa dalam meningkatkan pemahaman dan keilmuan mahasiswa. Penelitian ini bertujuan untuk mengetahui persepsi mahasiswa terhadap praktikum daring mata kuliah kimia analisis. Penelitian ini merupakan penelitian deskriptif kualitatif. Sampel diambil dengan menggunakan teknik simple random sampling berjumlah 45 mahasiswa. Data penelitian diperoleh dengan menggunakan kuesioner dan wawancara mendalam. Persepsi mahasiswa dilihat dari tiga aspek yaitu proses belajar mengajar, kemampuan dosen dan sarana dan prasarana yang dinilai menggunakan skala likert. Teknik analisis data yang digunakan dalam penelitian ini adalah analisis kualitatif yaitu pengumpulan data, reduksi data, penyajian data, dan penarikan kesimpulan. Secara keseluruhan persepsi mahasiswa pada semua aspek memiliki rerata 64,95\% sehingga persepsi mahasiswa terhadap praktikum daring mata kuliah kimia analisis adalah positif., persepsi mahasisa terhadap aspek belajar mengajar memiliki nilai 69,57\% yang menunjukkan persepsi positif, terhadap aspek kompetensi dosen memiliki nilai $77,90 \%$ yang menunjukkan persepsi positif terhadap aspek sarana prasarana memiliki nilai $47,39 \%$ yang menunjukkan persepsi positif.
\end{abstract}

Kata Kunci: persepsi mahasiswa; praktikum daring; kimis analisis

Submitted Nov 25, 2020 | Revised Des 20, 2020 | Accepted Des 23, 2020

\section{Pendahuluan}

Model perkuliahan dalam jaringan (daring) merupakan sistem pembelajaran jarak jauh yang menggunakan bantuan teknologi. Istilah daring merupakan akronim dari dalam jaringan. Jadi perkuliahan daring adalah salah metode pembelajaran online atau dilakukan melalui jaringan internet (Mustofa et al., 2019) Selama masa pandemi COVID-19 mengharuskan setiap satuan pendidikan menggunakan pembelajaran jarak jauh, itu menjadi satu satunya cara agar proses pembelajaran dapat terus berjalan. Proses pembelajaran daring tidak hanya untuk mata kuliah teori, namun juga untuk mata kuliah praktik (Hermawan et al., 2019). Mata kuliah Kimia Analisis, terdiri dari 2 satuan kredit semester (sks) kuliah dan 1 sks praktikum, diberikan kepada mahasiswa Program Studi Farmasi di semester II 
tahun akademik 2019/2020 dan diajarkan untuk memenuhi standar kompetensi lulusan pendidikan sarjana farmasi yaitu menunjukkan penguasaan IPTEK, kemampuan riset, dan kemampuan pengembangan diri. Mata kuliah ini membahas tentang Analisis kualitatif senyawa anorganik (reaksi pendahuluan, penggolongan, penetapan) dan identifikasi gugus fungsi senyawa organik dari senyawa obat yang terdapat dalam Farmakope Indonesia. Analisis kuantitatif konvensional, titrasi asam-basa, redoks, argentometri, kompleksometri, dan gravimetri dari senyawa terpilih yang terdapat dalam Farmakope Indonesia. Praktik/praktikum pada hakikatnya diselenggarakan untuk mengasah ke tiga ranah ranah pembelajaran (kognitif, afektif, dan psikomotor) walau penekanannya pada ranah psikomotorik, evaluasi penyelenggaraan praktikum perlu dilakukan, karena evaluasi memberikan bahan-bahan pertimbangan untuk menentukan/ membuat kebijakan tertentu, yang diawali dengan suatu proses pengumpulan data yang sistematis (Sadjati, 2013) Persepsi mahasiswa terhadap pembelajaran daring pada mata kuliah praktik masih ada yang bersifat negatif, dengan rincian aspek belajar mengajar sebesar 33,6\%, aspek kapabilitas (kemampuan dosen) sebesar 25,4\%, dan aspek sarana dan prasarana sebesar 27,3\% (Maulana \& Hamidi, 2020). Respons mahasiswa terkait dengan aktifitas pembelajaran daring yang sudah dilaksanakan selama kurang lebih 3 bulan menunjukan bahwa aktivitas daring yang dilaksanakan menjenuhkan dan membosankan (Aswasulasikin, 2020). Persepsi mahasiswa terhadap kuliah online dapat membantu mahasiswa dalam pelaksanaan proses perkuliahan di masa pandemi covid 19, karena perkuliahan yang baik dan benar akan membantu mahasiswa dalam meningkatkan pemahaman dan keilmuan mahasiswa (Anhusadar, 2020). Untuk itu, perlu dilaksanakan penelitian untuk mengetahui persepsi mahasiswa farmasi terhadap praktikum daring mata kuliah kimia analisis.

Persepsi adalah proses yang menyangkut masuknya pesan atau informasi kedalam otak manusia. Persepsi merupakan keadaan integrated dari individu terhadap stimulus yang diterimanya. Apa yang ada dalam diri individu, pikiran, perasaan, pengalamanpengalaman individu akan ikut aktif berpengaruh dalam proses persepsi. Persepsi dipengaruhi oleh faktor internal seperti fisiologis, perhatian, minat, kebutuhan, pengalaman dan ingatan serta suasana hati dan juga faktor eksternal merupakan karakteristik dari linkungan dan obyek-obyek yang terlibat didalamnya (Pinaryo, 2016). Persepsi mahasiswa terhadap pelaksanaan perkuliahan dan pembelajaran dapat dilihat dari beberapa poin, antara lain pelaksanaan perkuliahan, kondisi fisik, materi pembelajaran dan proses atau cara penyampaian materi pembelajaran. Pelaksanaan perkuliahan adalah aktivitas pembelajaran mahasiswa secara terprogram dalam jangka waktu tertentu dalam tataran operasional, pelaksanaan perkuliahan di lakukan melalui proses pembelajaran baik di dalam maupun di luar kelas atau kampus. Yang dilakukan secara terprogram dalam jangka waktu tertentu (semester). Kondisi fisik dapat dilihat dari ketersediaan sarana dan prasarana yang mendukung proses belajar mengajar. Bahan atau materi pembelajaran merupakan medium untuk mencapai tujuan pengajaran yang di konsumsi oleh peserta didik, bahan ajar merupakan materi yang terus berkembang secara dinamis seiring dengan kemajuan dan tuntutan perkembangan masyarakat. Bahan ajar yang diterima anak didik harus mampu merespon setiap perubahan dan mengantisipasi setiap perkembangan yang akan terjadi di masa depan. Menyampaikan materi pembelajaran adalah salah satu tugas pokok guru atau dosen sehari-hari, keterampilan-keterampilan tertentu seperti keterampilan berkomunikasi, menggunakan media dan penguasaan materi pembelajaran menentukan kualitas dalam penyampaian materi pembelajaran (Mukhtar, 2017). Selain itu, proses interaksi antar mahasiswa dengan dosen dapat menghasilkan persepsi mahasiwa tentang sosok dosen yang di ketahuinya. Mahasiswa menganggap dosen sebagai figur yang menarik dan menyenangkan, sehingga hal ini akan meningkatkan minat mahasiswauntuk mengikuti mata pelajaran yang diampunya. Persepsi mahasiswa akan menentukan sikapnya terhadap lingkungan dalam hal ini terhadap dosen. Dimana mahasiswa yang mempunyai persepsi positif terhadap dosen seringkali akan mempunyai sikap yang positif juga pada dosen itu terlebih kepada matakuliah yang diampunya, ketika mahasiswa mempersepsikan profesionalisme dosennya secara positif, maka sikap yang positif terhadap 
dosen itu juga terbentuk secara positif (Virgana, 2017). Persepsi mahasiswa dapat dinilai dari aspek kegiatan belajar mengajar, profesionalisme dosen, sarana dan prasarana pembelajaran.

Pembelajaran kimia tidak lepas dari kegiatan praktikum. Praktikum dalam proses pembelajaran sangat berperan dalam menunjang keberhasilan proses belajar kimia karena mahasiswa mendapat kesempatan untuk menguji dan melaksanakan dalam keadaan nyata apa yang diperoleh dari teori serta dimaksudkan untuk memantapkan penguasaan materi agar lebih mudah dipelajari. Pelaksanaan praktikum di Laboratorium kimia sangat tergantung pada ketersediaan alat dan bahan, personil laboran, instruktur (pengampu praktikum) dan asisten praktikum (Aladawiyah; et al., 2018). Pemanfaatan platform online semakin meningkat dalam dunia pendidikan, khususnya di perguruan tinggi. Konsep pembelajaran online yang kemudian lebih dikenal dengan istilah online learning (ol-learning) metode interaksinya berbeda dengan pembelajaran konvensional (conventional learning). Ol-learning menyediakan konten yang dibutuhkan untuk pembelajaran. Hampir semua mahasiswa mem-iliki laptop/smartphone/tablet, sehingga akses terhadap materi belajar semakin mudah dan sangat memungkinan bagi mahasiswa untuk saling berbagi konten pembelajaran melalui perangkat elektronik. Kondisi seperti ini mem-buat konten pembelajaran semakin lebih cepat didapatkan. Selain itu, ollearning memungkinkan fleksibilitas akses, mahasiswa dapat dengan mudah mengakses konten pembelajaran dimana saja dan kapan saja, tanpa terhalang ruang dan waktu (Sukardi \& Rozi, 2019). Pembelajaran online saat ini merupakan salah satu bentuk pembelajaran alternatif yang dapat dilaksasnakan selama masa darurat Covid-19. Pembelajaran online pada pelaksanaannya membutuhkan dukungan perangkat-perangkat mobile seperti telepon pintar, tablet dan laptop yang dapat digunakan untuk mengakses informasi dimana saja dan kapan saja (Firman \& Rahayu, 2020). Selain itu, sarana dan prasarana pendidikan merupakan salah satu sumber daya yang penting dalam menunjang proses pembelajaran agar pencapaian tujuan pembelajaran dapat berjalan dengan lancar. Pada pembelajaran daring mata kuliah praktik, selain membutuhkan perangkat-perangkat mobile, juga diperlukan perangkat/peralatan untuk melakukan praktikum di rumah sesuai dengan petunjuk yang diberikan (Maulana \& Hamidi, 2020).

\section{Metode Penelitian}

Penelitian ini merupakan penelitian deskriptif kualitatif. Populasi penelitian ini adalah seluruh mahasiswa Farmasi Universitas Nahdlatul Ulama Sunan Giri Bojonegoro (UNUGIRI) yang sedang melaksnakan praktikum daring mata kuliah kimia analisis. Sampel diambil dengan menggunakan teknik simple random sampling yang berjumlah 46 mahasiswa. Data penelitian diperoleh dengan menggunakan kuesioner dengan menggunakan Google Form yang diisi secara daring oleh mahasiswa dan juga wawancara mendalam kepada beberapa mahasiswa untuk mendapatkan informasi yang lebih mendetail. Persepsi mahasiswa dilihat dari tiga aspek yaitu proses belajar mengajar, kemampuan dosen dan sarana dan prasarana yang dinilai menggunakan skala likert. Teknik analisis data yang digunakan dalam penelitian ini adalah analisis kualitatif yaitu pengumpulan data, reduksi data, penyajian data, dan penarikan kesimpulan. Tingkat persepsi mahasiswa dalam penelitian ini mengacu pada standar pengukuran yaitu: Negatif jika persentase rerata total butir komponen $\leq 40 \%$, dan positif jika persentase rerata total butir komponen $>40 \%$.

\section{Hasil dan Pembahasan}

Responden merupakan mahasiswa semester 2 S1 Farmasi Universitas Nahdlatul Ulama Sunan Giri Bojonegoro yang mengambil mata kuliah praktikum kimia analisis. Berdasarkan hasil penelitian $89,1 \%$ responden adalah perempuan. Usia responden 56,5\% >19 tahun. Status pekerjaan responden $78,3 \%$ adalah mahasiswa. Namun ada 13\% responden yang juga bekerja secara offline. Gambaran umum responden disajikan pada tabel 1. 
Tabel 1.Gambaran Umum Responden

\begin{tabular}{lcc}
\hline Karakteristik Responden & $\mathrm{f}$ & $\%$ \\
\hline Jenis Kelamin & & \\
$\quad$ Laki-laki & 5 & $10,9 \%$ \\
$\quad$ Perempuan & 41 & $89,1 \%$ \\
Usia & & \\
$\quad$ 17-19 tahun & 20 & $43,5 \%$ \\
$\quad>19$ tahun & 26 & $56,5 \%$ \\
Status Pekerjaan & & \\
$\quad$ Mahasiswa & 36 & $78,3 \%$ \\
$\quad$ Mahasiswa dan bekerja offline & 6 & $13 \%$ \\
$\quad$ Mahasiswa dan bekerja online & 4 & $8,7 \%$ \\
\hline
\end{tabular}

Persepsi mahasiswa farmasi terhadap praktikum daring dinilai berdasarkan kuesioner yang disebar. Kuesioner terdiri atas tiga bagian yaitu proses belajar mengajar, kapabilitas (kompetensi dosen), dan sarana dan prasarana. Secara keseluruhan persepsi mahasiswa pada semua aspek memiliki rerata 64,95\% sehingga persepsi mahasiswa terhadap praktikum daring mata kuliah kimia analisis adalah positif. Data persentase rerata total butir komponen disajikan pada tabel 1.

Tabel 2. Persentase Rerata Total Butir Komponen Kuesioner yang Diisi oleh Responden

\begin{tabular}{lcc}
\hline No & \multicolumn{1}{c}{ Item } & $\%$ \\
\hline 1 & Aspek kegiatan belajar mengajar & $69,57 \%$ \\
2 & Aspek profesionalisme dosen & $77,9 \%$ \\
3 & Aspek sarana dan prasarana & $47,39 \%$ \\
Rata-rata semua aspek & $64,95 \%$ \\
\hline
\end{tabular}

Hasil penelitia menunjukkan bahwa persepsi mahasiswa terhadap praktikum daring pada mata kuliah praktikum kimia analisis dari aspek proses belajar mengajar bersifat positif sebesar $69,57 \%$. Pelaksanaan proses belajar mengajar adalah kegiatan dari seorang dosen sebagai tenaga pengajar yang berhubungan dengan mahasiswa sebagai subjek belajar. Hal ini mengimplikasikan bahwa proses belajar mengajar merupakan suatu proses interaksi dosen dengan mahasiswa yang bersifat mendidik dalam rangka mencapai tujuan pendidikan (Fibriana, Betty Aristha, 2014). Konsep belajar mengajar masih memiliki makna sebagai sebuah interaksi antara dosen dengan mahasiswa melalui sebuah pertemuan yang terjadi secara kasat mata di dalam kelas. Dosen atau pengajar berperan sangat dominan di dalam ruang kuliah. Padahal, pembelajaran yang efektif seharusnya sangat terfokus pada karakteristik yang tergambar dari (proses) pembelajarannya Kelas maya, secara substansial, seharusnya memang tidak berbeda dengan kelas nyata. Dosen berencana membangun kelas maya dan menggunakan semua teknologi yang cocok bagi mahasiswa course yang diampu (Darmayanti et al., 2007). Pada penelitian ini, persepsi baik terhadap aspek kegiatan belajar mengajar disebabkan oleh pemilihan platform yang tepat karena memungkinkan adanya interaksi antara dosen dan mahasiswa secara langsung dan juga adanya simulasi yang dilakukan dosen di laboratorium.

Pada penelitian ini, aspek belajar mengajar terdiri dari beberapa indikator yaitu kemudahan akses, pemahaman teori dan keterampilan, kesesuaian materi dengan kontrak dan kemudahan dalam mengirimkan tugas/laporan praktikum. Pada indikator kemudahan akses didapatkan hasil bahwa 65,65\% dapat diakses baik oleh mahasiswa, namun masih ada sekitar 19,34\% yang sangat sulit mendapatkan akses pembelajaran daring. Hal ini sesuai dengan penelitian yang dilakukan oleh Maulana \& Hamidi (2020) yang menunjukkan bahwa pelaksanaan perkuliahan daring dapat diakses oleh mahasiswa secara biasa sebesar $74 \%$, sedangkan 20\% mahasiswa mengalami kesulitan dan terdapat $6 \%$ 
mahasiswa yang sangat sulit untuk mengakses pembelajaran secara daring. Penelitian tentang e-learning memperlihatkan 91\% mahasiswa menyatakan e-learning mudah untuk diakses. Sebagian besar mahasiswa mengakses e-learning dengan menggu-nakan web browser baik dari smarthpone maupun laptop, hal ini dikarenakan dalam prosesnya belum dapat diselaraskan dengan android. Praktikum daring mata kuliah kimia analisis dilakukan dengan platform youtobe dengan cara live (langsung) dimana saat jadwal praktikum, dosen menjelaskan materi melalui youtobe lalu dilakukan pemutaran video simulasi praktikum yang telah direkam sebelumnya di laboratorium sentral farmasi Universitas Nahdlatul Ulama Sunan Giri Bojonegoro. Pada kesempatan ini, terdapat kesempatan berinteraksi secara langsung antara dosen dan mahasiswa saat praktikum berlangsung. Bagi beberapa mahasiswa, berdasarkan hasil wawancara, penyebab terbesar kesusahan mengakses adalah sinyal, kuota dan ram HP. Mahasiswa Farmasi Universitas Nahdlatul Ulama Sunan Giri Bojonegoro berasal dari berbagai kelurahan yang tersebar di Kabupaten Bojonegoro, Kabupaten Lamongan dan Kabupaten Tuban. Beberapa yang tinggal di daerah terpencil mengaku kesusahan mendapatkan sinyal, seperti yang diungkapkan oleh beberapa responden

\section{Hambatan saya adalah jaringan, karena rumah saya dikaki gunung dan sinyalnya susah. (responden 17)}

Saya merasa akses perkuliahan dering ini tidak maksima,l terlebih jika terhambat oleh jaringan di desa saya sangat susah didapatkan dan bisa menyebabkan ketinggalan dalam mengikuti perkuliahan (responden 31)

Selain itu, penggunaan platform youtube juga menyebabkan kuota mahasiswa lebih cepat habis, seperti yang disebutkan responden berikut ini

Ada sib kuota khusus youtube, tapi ya gitu, tetep aja cepet abis, Iha yang diliat cuma 1 video dalam 1 hari, mata kuliahnya saja satu hari bisa 3-4 mata kuliah (responden 7)

Ada juga responden yang merasa hambatan lainnya adalah RAM HP,

Yang agak. mengganggu adalah gangguan sinyal dan ram hp yang kurang memadai (responden 25)

Pada indikator pemahaman teori dan keterampilan, 60,43\% mahasiswa memiliki persepsi positif, hal ini dikarenakan pada saat menyampaikan materi, dosen juga menjelaskan secara rinci langkahlangkah praktikum, hasil praktikum yang benar, dan juga kemungkinan kesalahan dalam praktikum.

Tetap bisa jelas tentang praktikumnya, karena dijelaskan perlahan-lahan, teratur di tiap langkahnya. Dosen juga memberi tahu apa saja yang bisa jadi penyebab kesalahan praktikum. Babkan dosen juga melakukan sendiri praktiknya di lab farmasi, sehingga bisa pabam dan mengerti caranya (responden 4)

Setiap pembelajaran selalu dijelaskan dengan jelas dan pada masa pandemiba pak dosen kimia analisis adalah dosen terbaik karena sudah niat untuk. menjelaskan kami dengan cara bapak sendiri yang membuat kami lebih mengerti (responden 22)

Meskipun dilaksanakan secara daring, 81,3\% mahasiswa menyatakan bahwa maetri praktikum tetap disesuikan dengan kontrak praktikum yang sebelumnya telah dilakukan secara offline sebelum pandemi covid-19, seperti yang diungkapkan oleh responden no 30

Praktikum daring elalu tepat waktu, memberikan materinya secara tepat dan sesuai dengan RPS yang disebar saat awal-awal dulu

Untuk pembuatan dan pengiriman laporan praktikum, 64,35\% mahasiswa menyatakan kalau pengiriman laporan sudah baik, seperti yang diungkapkan salah satu responden. 
Laporannya harus ditulis tangan lalu dikirimkan ke asisten praktikum. Jika ada revisi, maka asisten akan memberi kesempatan revisi (responden 3)

Persepsi pada kompetensi profesional dosen adalah proses ketika mahasiswa menerima, mengorganisasikan dan menginterpretasi kemampuan, pengetahuan, ketrampilan, dan perilaku yang dimiliki dosen pada saat mengajar. Persepsi mahasiswa pada profesionalisme dosen secara positif mempengaruhi langsung pemahaman konsep diferensial, maka pelatihan dan pembinaan (Virgana, 2017). Penilaian kompetensi profesional dosen pada penelitian ini dinilai dari beberapa indikator seperti kemampuan dosen dalam menjelaskan arah dan tujuan dalam praktikum daring, adanya interaksi antara dosen dan mahasiswa saat praktikum daring, adanya respon positif dosen terhadap pertanyaan mahasiswa selama praktikum daring. Dari kuesioner yang disebar, aspek kapabilitas (kemampuan dosen) mendapatkan persentase rerata sebesar $77,9 \%$ sehingga dapat dikategorikan persepsi mahasiswa terhadap aspek kapabilitas (kemampuan dosen) pada pembelajaran daring untuk mata kuliah praktik adalah positif. Hasil penelitian sesuai dengan penelitian tentang efektifitas e-learning pada mata kuliah kimia dimana sebagian besar mahasiswa puas dan menikmati proses pembelajaran e-learning dimana sebagian besar mahasiswa memiliki persepsi yag baik terhadap performa dosen pengampu perkuliahan kimia (Hermawan et al., 2019). Hasil penelitian tidak sesuai dengan penelitian tentang praktikum kimia yang menunjukkan persepsi mahasiswa terhadap peran dan efektifitas bimbingan instruktur serta peran instruktur selama pelaksanaan yang masih kurang (Aladawiyah; et al., 2018). Dasar dari persepsi mahasiswa tehadap kompetensi dosen adalah apa yang dirasakan oleh mahasiswa, perbedaan dosen dan kriteria responden dapat mempengaruhi persepsi mahasiswa. Ini menunjukkan dosen mata kuliah praktikum kimia analisis adalah dosen yang profesional. Hal ini dikarenakan dosen adalah lulusan linier untuk ilmu kimia dan sudah 2 tahun mengajar serta memiliki pengalaman 3 tahun mengajar bimbingan belajar serta termasuk dosen yang memiliki kemampuan yang baik dalam pelaksanaan e-learning, sehingga persepsi mahasiswa terhadap dosen yang bersangkutan adalah positif. Menurut mahasiswa, arah dan tujuan praktikum dijelaskan dengan baik oleh dosen.

Pak dosennya di awal selalu menjelaskan kalau praktikum ini tujuannya apa, meskipun sudah ada di buku panduan, tapi tetap diulang-ulang (responden 42)

Praktikum dilaksanakan secara live dengan sebelumnya telah diberikan informasi tentang apa yang harus disiapkan. Selama praktikum daring dilaksanakan, selalu ada interaksi antara dosen dan mahasiswa, dosen juga selalu memberikan respon positif terhadap pertanyaan mahasiswa selama praktikum daring.

Seperti praktikum biasa, kalau ada yang bingung ya tanya, lalu dijawab sama dosennya. Dosennya juga tidak marah kalau pertanyaan dari temen-teen banyak, paling kalau pertanyaannya sudah ada jawabannya di buku panduan beliaunya sambil bercanda bilang kalau kita tidak membaca panduan. Meski agak nyelekit, tapi masib baik kok, karena tidak pakai nada tinggi (responden 2)

Sarana dan prasarana yang dimiliki oleh sebuah laboratorium menunjang kegiatan ilmiah, eksperimentasi sehingga terdapat penemuan baru dalam bidang keilmuan yang membawa pembaharuan. Dilihat dari segi pelanggan, laboratorium merupakan suatu tempat dimana dosen dan mahasiswa, guru dan siswa, dan orang lain yang melaksanakan kerja ilmiah dalam rangka kegiatan belajar mengajar. Dilihat dari segi kerjanya, laboratorium merupakan suatu tempat untuk kegiatan kerja juga dapat menghasilkan sesuatu. Untuk itu, kelengkapan sarana dan prasarana laboratorium penting dalam pelaksanaan praktik di laboratorium (Nyangko et al., 2016). Persepsi mahasiswa terhadap praktikum daring mata kuliah kimia analisis pada aspek sarana dan prasarana dinilai dari indikator ketersediaan alat dan bahan praktikum di rumah mahasiswa. Hasil penelitian menunjukkan bahwa $77,93 \%$ responden tidak memiliki alat dan baham yang digunakan untuk praktikum. Untuk itu, ada 
beberapa judul praktikum dilakukan secara demonstrasi oleh dosen di laboratorium farmasi universitas nahdlatul ulama sunan giri bojonegoro dan mahasiswa melakukan simulasi di rumah masing-masing, melainkan secara simulasi. Demonstrasi adalah metode mengajar dengan cara memperagakan barang, kejadian, aturan, dan urutan melakukan suatu kegiatan, sedangkan simulasi adalah sebuah replikasi atau visualisasi dari perilaku sebuah sistem (Raharjo, 2017).

Kalau praktikumnya nggak, punya alat dan bahannya, ya cuma interaksi dari video yang diberikan dosen lalu kita simulasi, simulasinya itu kita menyiapkan alat dan bahannya dalam bentuk gambar jadi masib bisa praktik cara-cara praktikumnya (responden 4)

Secara keseluruhan aspek sarana dan prasarana mendapatkan persentase rerata sebesar 47,39\% sehingga dapat dikategorikan persepsi mahasiswa terhadap aspek sarana dan prasarana pada pembelajaran daring untuk mata kuliah praktik adalah positif. Hasil ini sesuai dengan penelitian yang dilakukan oleh Musiana (2015) yang menunjukkan bahwa persemsi mahasiswa terhadap sarana dan prasarana laboratorium sebagian besar baik. Hal ini dikarenakan laboratorium farmasi universitas nahdlatul ulama sunan giri bojonegoro memiliki alat dan bahan yang lengkap untuk mendukung pembelajaran praktik mata kuliah kimia, termasuk mata kuliah kimia analisis

\section{Kesimpulan}

Persepsi mahasiswa terhadap praktikum daring mata kuliah kimia analisis dapat dilihat dari aspek proses belajar mengajar, aspek kompetensi dosen dan aspek sarana prasarana. Dari hasil penelitian, persepsi mahasisa terhadap aspek belajar mengajar 69,57\% positif, terhadap aspek kompetensi dosen $77,9 \%$ positif dan terhadap aspek sarana prasarana $47,39 \%$ positif.

\section{Daftar Pustaka}

Aladawiyah;, Masriani;, \& Sartika, R. (2018). Analisis Keterlaksanaan Praktikum Kimia di Laboratorium Program Studi Pendidikan Kimia Universitas Tanjungura Pontianak. Jumal Pendidikan Dan Pembelajaran Khatulistiwa, 7(7), 1-13.

Anhusadar, L. O. (2020). Persepsi Mahasiswa PIAUD terhadap Kuliah Online di Masa Pandemi. KINDERGARTEN: Journal of Islamic Early Childhood Education, 3(1), 44-58. https://www.researchgate.net/publication/341151841_Persepsi_Mahasiswa_PIAUD_terhadap _Kuliah_Online_di_Masa_Pandemi_Covid_19

Aswasulasikin. (2020). Persepsi Mahasiswa Terhadap Kuliah Daring dimasa Pandemi Corona Virus Disease (COVID-19). SALAM Jurnal Sosial Dan Budaya Syar'i.

Darmayanti, T., Setiani, M. Y., \& Oetojo, B. (2007). E-Learning Pada Pendidikan Jarak Jauh: Konsep Yang Mengubah Metode Pembelajaran Di Perguruan Tinggi Di Indonesia. Jurnal Pendidikan Terbuka Dan Jarak Jauh, 8, 99-113.

Fibriana, Betty Aristha, A. K. (2014). Persepsi Mahasiswa Terhadap Pelaksanaan Proses Belajar Mengajar Universitas Negeri Surabaya. 337-344.

Firman, F., \& Rahayu, S. (2020). Pembelajaran Online di Tengah Pandemi Covid-19. Indonesian Journal of Educational Science (IJES), 2(2), 81-89. https://doi.org/10.31605/ijes.v2i2.659

Hermawan, A., Ikawati, M., Kristina, S. A., \& Meiyanto, E. (2019). Efektivitas Hybrid e-Learning Mata Kuliah Kimia Klinik dan Bioanalisis di Fakultas Farmasi, Universitas Gadjah Mada. Jurnal Manajemen Dan Pelayanan Farmasi (Journal of Management and Pharmacy Practice), 9(3), 164-173. https://doi.org/10.22146/jmpf.42718

Maulana, H. A., \& Hamidi, M. (2020). Persepsi Mahasiswa terhadap Pembelajaran Daring pada Mata Kuliah Praktik di Pendidikan Vokasi. Equilibrium: Jumal Pendidikan, VIII(2), 224-231. 
Mukhtar. (2017). Persepsi Mahasiswa terhadap Pelaksanaan Perkuliahan dan Hubungannya dengan Partisipasi Mahasiswa dalam Perkuliahan. Jom FISIP, 4(2), 2-15. https://doi.org/10.1063/1.4981832

Musiana. (2015). Persepsi Mahasiswa terbadap Pembelajaran Praktik Laboratorium di Jurusan Keperawatan Tanjungkarang. Hussein Ratna M, VI.

Mustofa, M. I., Chodzirin, M., Sayekti, L., Negeri, U. I., \& Semarang, W. (2019). Formulasi Model Perkuliahan Daring Sebagai Upaya Menekan Disparitas Kualitas Perguruan Tinggi (Studi terhadap Website pditt.belajar.kemdikbud.go.id). Walisongo Journal of Information Technology, 1(2), 151-160. https://doi.org/10.21580/wjit.2019.1.2.4067

Nyangko, L. R., Karo Karo, U., \& Hamdani, A. (2016). Penggunaan Laboratorium Dalam Menunjang Proses Pembelajaran Teknik Pemesinan. Journal of Mechanical Engineering Education, 1(1), 102. https://doi.org/10.17509/jmee.v1i1.3742

Pinaryo. (2016). Persepsi Mahasiswa Universitas Muhammadiyah Ponorogo Terhadap Program Kewirausahaan Mahasiswa. Aristo, 2(2), 53. https://doi.org/10.24269/ars.v2i2.22

Raharjo, S. (2017). Pengaruh Metode SDEP (Simulasi, Demonstrasi, Eksperimen, Presentasi) dan Kemampuan Awal Siswa Terhadap Hasil Belajar Fisika. Jurnal Penelitian Pembelajaran Fisika, 8(1), 51-56. https://doi.org/10.26877/jp2f.v8i1.1337

Sadjati, I. M. (2013). Persepsi Mahasiswa Tentang Penyelenggaraan Praktikum Pada Pendidikan Tinggi Terbuka Jarak Jauh. Pendidikan Terbuka Dan Jarak Jauh, 14(1), 46-46.

Sukardi, S., \& Rozi, F. (2019). Pengaruh Model Pembelajaran Online Dilengkapi Dengan Tutorial Terhadap Hasil Belajar. JIPI (Jurnal Ilmiah Penelitian Dan Pembelajaran Informatika), 4(2), 97. https://doi.org/10.29100/jipi.v4i2.1066

Virgana. (2017). Persepsi Mahasiswa Pada Profesionalisme Dosen, Minat Belajar Dan Pemahaman Konsep Diferensial. Jurnal Ilmiab Kependidikan, 4(2), 170. 